Jurnal Penelitian dan Pengabdian Kepada Masyarakat Bidang ilmu Pendidikan

\title{
Evaluasi Kepercayaan Mahasiswa Terhadap STIE Yapis Dompu Menggunakan Structural Equation Modeling
}

\author{
Yeye Suhaety \\ Program Studi Manajemen, STIE Yapis Dompu, Nusa Tenggara Barat, Indonesia \\ E-mail:yeyen.suhaety@gmail.com
}

Article History: Received: 2022-02-11 || Revised: 2022-02-15 || Published: 2022-02-28

Sejarah Artikel : Diterima: 2022-02-11 || Direvisi: 2022-02-15 || Dipublikasi: 2022-02-28

\begin{abstract}
This research aims to determine the effect of college reputation and service quality on the trust of STIE Yapis Dompu students which will have an impact on the decision to choose the college. This study uses a quantitative approach with a total of 140 respondents determined by simple random sampling technique. Data were collected by questionnaire and statistically processed using Structural Equation Modeling (SEM) through the AMOS program. The results showed that there was a positive and significant effect of the STIE Yapis Dompu college reputation variable on student confidence ( $C R$ value $4.952>1.96$; $\mathrm{P}=0.000<0.05$ ). The trust variable also has a positive and significant influence on students' decisions to choose STIE Yapis Dompu tertiary institutions $(\mathrm{CR}$ value $=6.440>1.96 ; \mathrm{P}=0.000<0.05)$. As for the service quality variable, in this research it has a smaller direct positive effect on student confidence $(C R=2.461>1.96 ; \mathrm{P}=0.014<0.05$ ) when compared to the influence of the reputation of the STIE Yapis Dompu college.
\end{abstract}

Keywords: Evaluation, Trust, Students, Service Quality, STIE Yapis Dompu.

\begin{abstract}
Abstrak
Penelitian ini bertujuan untuk mengetahui pengaruh reputasi perguruan tinggi dan kualitas layanan terhadap kepercayaan mahasiswa STIE Yapis Dompu yang akan berdampak pada keputusan memilih perguruan tinggi tersebut. Penelitian ini menggunakan pendekatan kuantitatif dengan jumlah responden sebanyak 140 yang ditentukan dengan tehnik simple random sampling. Data dikumpulkan dengan kuesioner dan diolah secara statistik menggunakan Structural Equation Modeling (SEM) melalui program AMOS. Hasil penelitian menunjukkan bahwa terdapat pengaruh positif dan signifikan dari variabel reputasi perguruan tinggi STIE Yapis Dompu terhadap kepercayaan mahasiswa (nilai CR 4,952 > 1,96; $\mathrm{P}=0,000<0.05$ ). Variabel kepercayaan juga memiliki pengaruh positif dan signifikan terhadap keputusan mahasiswa memilih perguruan tinggi STIE Yapis Dompu (nilai CR $=6,440>1,96 ; \mathrm{P}=0,000<0,05$ ). Adapun variabel kualitas layanan, dalam penelitian ini memberikan pengaruh positif secara langsung yang lebih kecil terhadap kepercayaan mahasiswa $(C R=2,461>1,96 ; \mathrm{P}=0,014<0,05)$ apabila dibandingkan dengan pengaruh reputasi perguruan tinggi STIE Yapis Dompu.
\end{abstract}

Kata kunci: Evaluasi, Kepercayaan, Mahasiswa, Kualitas layanan, STIE Yapis Dompu.

\section{PENDAHULUAN}

Perguruan tinggi sebagai salah satu bagian penting dalam dunia pendidikan yang ikut bertanggungjawab dalam upaya mencerdaskan kehidupan bangsa mempunyai tanggung jawab dan peran yang sangat strategis untuk mengambil bagian dalam mengatasi permasalahan kualitas sumber daya manusia. Hal ini didukung oleh kebijakan pemerintah yang memberikan kesempatan seluas-luasnya kepada semua komponen masyarakat untuk berpartisipasi dalam pembangunan pendidikan di Indonesi serta untuk memberdayakan peran serta masyarakat menyelenggarakan pendidikan berdasarkan prinsip otonomi dalam konteks negara kesatuan Republik Indonesia khususnya pendidikan tinggi. Berdasarkan data dari PD Dikti tercatat pertumbuhan perguruan tinggi di Indonesia terus mengalami peningkatan hingga tahun 2014 sudah berjumlah 4.341 perguruan tinggi. Adapun sebaran perguruan tinggi tersebut antara lain Akademi berjumlah 1.137, Politeknik berjumlah 225, Sekolah Tinggi 2364, Institut 110 dan Universitas berjumlah 505. Peningkatan ini berdampak pada meningkatnya persaingan di antara perguruan tinggi itu sendiri dalam menggaet calon mahasiswa. Masing-masing perguruan tinggi ini bersaing memberikan pelayanan jasa pendidikan terbaik dan berlomba-lomba mendapatkan kepercayaan dari mahasiswa 
agar memilih perguruan tinggi mereka. Berbagai potensi dan keunggulan yang dimiliki akan dikerahkan semaksimal mungkin dan menjadi nilai jual yang positip, namun sebaliknya perguruan tinggi yang tidak mampu dan tidak memiliki daya saing akan merasakan dampak dari persaingan ini berupa kurangnya jumlah mahasiswa. Di sisi lain pertumbuhan perguruan tinggi ini membuat para calon mahasiswa memiliki banyak alternatif dalam memilih sebuah perguruan tinggi.

Perguruan tinggi sebagai penyedia layanan pendidikan harus menekankan pada pemberian layanan yang berkualitas untuk memperoleh kepercayaan mahasiswa dan masyarakat luas. Jika mahasiswa dan masyarakat luas punya pandangan yang positif terhadap perguruan tinggi, maka kepercayaan masyarakat terhadap perguruan tinggi akan terbentuk. Selain kualitas layanan pendidikan, reputasi perguruan tinggi juga menentukan kepercayaan mahasiswa. Masyarakat terkadang memiliki pandangan sendiri dalam menentukan layanan pendidikan berdasarkan pada reputasi suatu perguruan tinggi. Bahkan masyarakat seringkali bersedia untuk membayar lebih mahal atas biaya studi pada perguruan tinggi tertentu yang dinilai memiliki reputasi baik. Reputasi sangat berharga karena menentukan sikap masyarakat terhadap produk, institusi atau individu tertentu.

Kepercayaan merupakan hal yang kompleks karena mencakup integritas, reliabilitas dan kepercayaan dengan satu kelompok yang ditempatkan dengan lainnya (Doney dan Cannon, 1997). Studi Morgan dan Hunt (1994) menggambarkan kepercayaan sebagai keberadaan suatu pihak ketika memiliki partner kerjasama yang dapat dipercaya dan memiliki integritas. Oleh karena itu perusahaan harus dapat membangun kepercayaan pelanggan melalui reputasi perusahaan dan dapat menunjukan kinerja yang baik serta profesional (So, May dan Dominic, 2002). Selain itu kualitas layanan yang dirasakan pelanggan sangatlah unik dan dapat mempengaruhi kepercayaan. Menurut Zeithaml et al (1990) bahwa tingkat kualitas layanan yang baik tercapai bila penyedia jasa mampu memenuhi bahkan melebihi apa yang menjadi harapan dari konsumen.

Salah satu penyedia jasa layanan pendidikan di Kabupaten Dompu Nusa Tenggara Barat adalah STIE Yapis Dompu yang berdiri sejak tahun 2000. Perguruan tinggi swasta ini telah mendapatkan akreditasi dari BAN-PT baik di tingkat institusi maupun program studi. Akreditasi menjadi begitu berharga karena berhubungan dengan peningkatan kualitas dan kepercayaan masyarakat terhadap STIE Yapis Dompu yang akhirnya akan membawa impikasi luas bagi mahasiswa maupun alumni. Meskipun belum ada program studi yang terakreditasi A, namun tidak mengurangi antusias masyarakat untuk melanjutkan pendidikan di perguruan tinggi tersebut. Terbukti dengan perolehan jumlah mahasiswa selama 3 tahun terakhir yang terus mengalami peningkatan, yaitu sebanyak 145 di tahun 2018 dan naik menjadi 410 mahasiswa pada tahun 2021 (Sumber : STIE Yapis Dompu, 2022).

Berdasarkan latar belakang yang telah diuraikan diatas, maka dirumuskan beberapa permasalahan sebagai berikut:

1. Apakah reputasi STIE Yapis Dompu berpengaruh terhadap kepercayaan mahasiswa?

2. Apakah kualitas layanan STIE Yapis Dompu berpengaruh terhadap kepercayaan mahasiswa?

3. Apakah kepercayaan mahasiswa berpengaruh terhadap keputusan memilih STIE Yapis Dompu?

\section{Kerangka Konseptual}

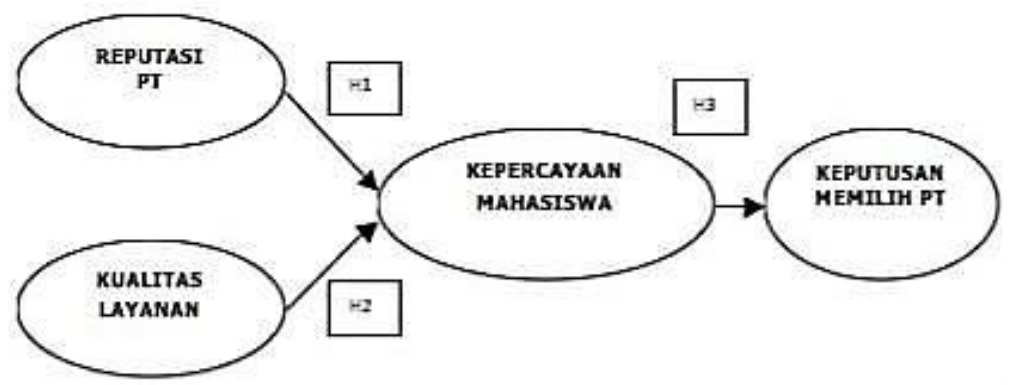

Gambar 1. Kerangka Konseptual

Berdasarkan kerangka konseptual tersebut, maka hipotesis yang diajukan dalam penelitian ini adalah:

H1: Diduga reputasi perguruan tinggi (PT) STIE Yapis Dompu berpengaruh positif terhadap kepercayaan mahasiswa 
H2: Diduga kualitas layanan perguruan tinggi STIE Yapis Dompu berpengaruh positif terhadap kepercayaan mahasiswa

H3: Diduga kepercayaan mahasiswa berpengaruh positif terhadap keputusan memilih STIE Yapis Dompu

\section{METODE PENELITIAN}

Penelitian ini merupakan penelitian kuantitatif, dengan populasi yang ditetapkan yaitu mahasiswa Prodi S1 Manajemen STIE YAPIS Dompu angkatan 2021. Mengingat keterbatasan waktu dan biaya penelitian, maka sampel perlu dibatasi. Adapun teknik pengambilan sampel yang digunakan adalah simple random sampling, yaitu mengambil sampel secara acak tanpa memperhatikan strata yang ada dalam dari populasi itu (Sugiyono,2012). Sampel adalah bagian yang dapat mewakili populasi dan memiliki karakteristik yang sama serta dianggap bisa mewakili populasi (Sugiyono, 2012). Jumlah sampel dalam penelitian yang sesuai dengan alat analisis yang akan digunakan yaitu Structural Equation Modeling (SEM) adalah minimal 100 (Ferdinand, 2006). Dan menurut Hair et al., (1998), penentuan jumlah sampel yang representatif untuk SEM adalah : (Jumlah indikator) x (5 sampai 10 kali). Berdasarkan pedoman tersebut, maka jumlah sampel maksimal untuk penelitian ini adalah 140 responden, teknik analisis yang digunakan dalam penelitian ini adalah Structural Equation Model (SEM) yang dioperasikan melalui program AMOS. Alasan penggunaan SEM adalah karena SEM merupakan sekumpulan teknik-teknik statistik yang memungkinkan pengukuran sebuah rangkaian hubungan yang relatif rumit secara simultan. Permodelan penelitian melalui SEM memungkinkan seorang peneliti dapat menjawab pertanyaan penelitian yang bersifat regresif maupun dimensional yaitu mengukur dimensi-dimensi dari sebuah konsep (Ferdinand, 2006). SEM juga dapat mengidentifikasi dimensi-dimensi sebuah konsep atau konstruk dan pada saat yang sama juga dapat mengukur pengaruh atau derajat hubungan faktor yang akan diidentifikasikan dimensi-dimensinya.

\section{HASIL DAN PEMBAHASAN}

\section{A. Hasil Penelitian}

Tahapan awal yang dapat dilakukan dalam menganalisis data yaitu dimulai dengan analisis deskriptif responden, selanjutnya dilakukan pengujian instrumen penelitian yang meliputi uji validitas reabilitas untuk mengetahui ketepatan dan kecermatan suatu alat ukur serta mengukur kehandalan atau konsistensi internal suatu instrumen penelitian. Hal tersebut dilakukan untuk menjamin kebenaran dan kualitas data penelitian yang diperoleh. Kemudian dilanjutkan dengan analisis data menggunakan SEM dan uji kesesuaian model menurut kriteria goodness of fit beserta pembahasannya. Tahapan terakhir adalah ulasan hasil uji struktural model hubungan antar variabel amatan yang dihipotesiskan.

\section{Analisis Deskriptif}

Dari 140 kuesioner yang di distribusikan, sebanyak 140 kuesioner terisi lengkap (100 \%). Berdasarkan hasil olah kuesioner, dapat disimpulkan bahwa perempuan mendominasi responden yaitu sebanyak 83 (59,3\%). Sedangkan menurut jenis pekerjaan orang tua, persentase terbesar ada pada petani $(86,4 \%)$.

2. Uji Validitas dan Reliabilitas

Penelitian ini menggunakan data kuesioner sebagai data primer, sehingga diperlukan langkah uji coba pertanyaan (kuesioner) untuk mengetahui apakah pertanyaan tersebut layak atau tidak. Uji untuk mengetahui layak (sahih) dan tidaknya pertanyaan adalah uji validitas. Uji ini digunakan untuk mengukur kesahihan dan kevalidan suatu item pertanyaan. Kriteria keputusannya adalah dengan membandingkan nilai Corrected Item - Total Correlation dibandingkan dengan nilai $r$ tabel (150) dengan tingkat $(\alpha) 0,05$ yaitu sebesar 0,159 . Kriteria keputusan, apabila nilai Corrected Item - Total Correlation lebih besar dari $\mathrm{r}$ tabel maka indikator layak (sahih) dan sebaliknya (Imam Ghozali, 2005), sedangkan uji instrumen lainnya adalah uji reliabilitas yaitu yang berhubungan dengan masalah ketepatan dari suatu data, dan untuk pengujian reliabilitas melalui nilai koefisien alpha yang dibandingkan nilai 0,60 . Konstruk atau variabel dikatakan reliabel apabila mempunyai nilai alpha diatas 0,60 dan sebaliknya (Imam Ghozali, 2005). Berdasarkan hasil perhitungan dengan program SPSS dapat disajikan pengujian validitas dan reliabilitas pada tabel berikut ini. 
Tabel 1. Hasil Pengujian Reliabilitas dan Validitas Kuesioner

\begin{tabular}{|c|c|c|c|}
\hline Konstruk/Variabel Laten & $\begin{array}{c}\text { Reliabilitas } \\
(\text { Crounbach } \alpha)\end{array}$ & $\begin{array}{c}\text { Item } \\
\text { (Indikator) }\end{array}$ & $\begin{array}{c}\text { Corrected Item - Total } \\
\text { Correlation }\end{array}$ \\
\hline \multirow{3}{*}{ Reputasi PT } & \multirow{3}{*}{0,786} & $\mathrm{X} 1$ & 0,660 \\
\hline & & $\mathrm{X} 2$ & 0,695 \\
\hline & & $\mathrm{X} 3$ & 0,542 \\
\hline \multirow{5}{*}{ Kualitas Layanan } & \multirow{5}{*}{0,915} & $\mathrm{X} 4$ & 0,850 \\
\hline & & $\mathrm{X} 5$ & 0,814 \\
\hline & & $\mathrm{X} 6$ & 0,704 \\
\hline & & $\mathrm{X} 7$ & 0,752 \\
\hline & & $\mathrm{X} 8$ & 0,810 \\
\hline \multirow{3}{*}{ Kepercayaan Mahasiswa } & \multirow{3}{*}{0,833} & $\mathrm{X} 9$ & 0,713 \\
\hline & & $\mathrm{X} 10$ & 0,674 \\
\hline & & $\mathrm{X} 11$ & 0,693 \\
\hline \multirow{3}{*}{ Keputusan Memilih PT } & \multirow{3}{*}{0,797} & $\mathrm{X} 12$ & 0,599 \\
\hline & & $\mathrm{X} 13$ & 0,648 \\
\hline & & $\mathrm{X} 14$ & 0,678 \\
\hline
\end{tabular}

Sumber : Data primer yang diolah, 2022

Pada tabel 1 diatas dapat ditunjukkan bahwa semua indikator (observed) adalah valid, hal ini ditandai dengan nilai Corrected Item - Total Correlation $>r$ tabel $(0,159)$. Pembuktian ini menunjukkan bahwa semua indikator (observed) layak digunakan sebagai indikator dari konstruk (laten variabel). Koefisien alpha (cronbach alpha) memiliki nilai di atas 0,60 sehingga dapat dijelaskan bahwa variabel - variabel penelitian (konstruk) yang berupa variabel reputasi perguruan tinggi, kualitas layanan, kepercayaan dan keputusan memilih perguruan tinggi adalah reliabel atau memiliki reliabilitas yang tinggi, sehingga mempunyai ketepatan untuk dijadikan variabel (konstruk) pada suatu penelitian.

3. Uji Full Model Structural Equation Modeling (SEM)

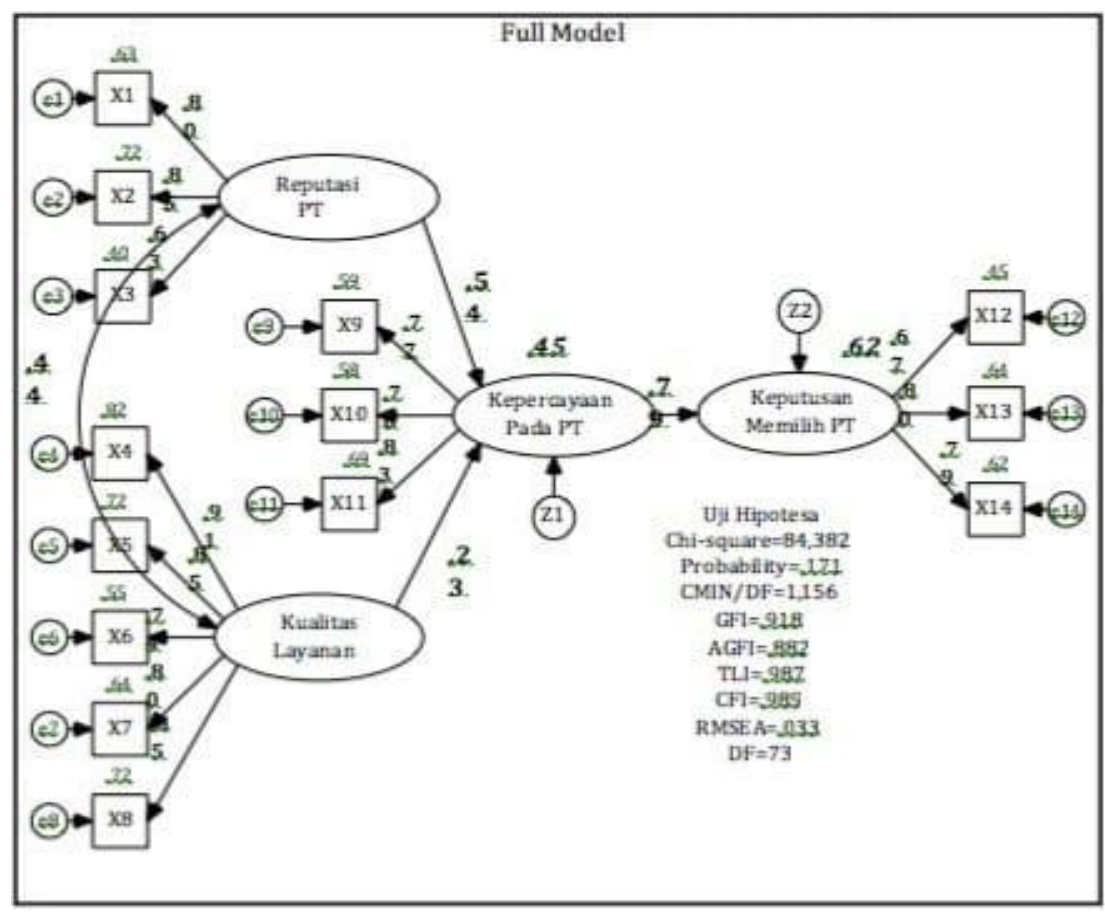

Gambar 2. Hasil Uji Full Model Structural Equation Modeling

Hasil pengolahan data untuk analisis uji full model ditampilkan pada gambar 2 . Berdasarkan persamaan model pada gambar 2 dan spesifikasi model pengukuran konstruk eksogen dan endogen yang dilihat dari nilai estimasi pada tabel 3, diperoleh hasil bahwa pengaruh tidak langsung reputasi terhadap keputusan memilih perguruan tinggi STIE Yapis Dompu melalui kepercayaan mahasiswa sebesar $(0,528) \times(0,720)=0,38016$. Sedangkan pengaruh tidak langsung kualitas layanan terhadap keputusan memilih perguruan tinggi STIE 
Yapis Dompu melalui kepercayaan mahasiswa adalah sebesar $(0,189) \times(0,720)=0,13608$.

4. Uji Kesesuaian Model (Goodness of Fit)

Selanjutnya perlu menilai kesesuaian goodness of fit sebelum melakukan pengujian hipotesis. Hasil pengujian dan evaluasi goodness of fit dari model penelitian dapat dilihat pada tabel berikut ini:

Tabel 2. Hasil Pengujian Goodness of Fit Model

\begin{tabular}{cccc}
\hline Kriteria & Cut of Value & Hasil & Evaluasi \\
\hline Chi-Square & $\chi^{2}$ dengan df : $73 ; \mathrm{p}: 5 \%=93,945$ & 84,382 & Baik \\
Probability & 0,05 & 0,171 & Baik \\
GFI & 0,90 & 0,918 & Baik \\
AGFI & 0,90 & 0,882 & Marginal \\
TLI & 0,95 & 0,987 & Baik \\
CFI & 0,95 & 0,989 & Baik \\
CMIN/DF & $<2,00$ & 1,156 & Baik \\
RMSEA & $<0,08$ & 0,033 & Baik \\
\hline
\end{tabular}

Sumber: Hasil yang dikembangkan untuk penelitian ini, 2022

Tabel 2 menunjukkan bahwa hasil pengukuran secara keseluruhan Goodness of Fit model dinyatakan baik. Nilai chi-square sebesar 84,382, nilai ini masih dibawah chi-square tabel untuk derajat kebebasan 73 dan pada tingkat signifikan $5 \%$ sebesar 93,945 dengan probablity level 0,171 maka menunjukkan indikasi baik atau fit. Goodness of Fit Indeks (GFI) memiliki nilai sebesar 0,918 lebih besar dari 0,90 sehingga dapat dikatakan memiliki tingkat kesesuaian model yang baik. Nilai RMSEA sebesar 0,033 menunjukkan tingkat kesesuaian yang baik. Hasil nilai AGFI sebesar 0,882 sedikit lebih kecil dari 0,90 (marginal). Dengan demikian secara keseluruhan model yang dikembangkan adalah baik. TLI menunjukan tingkat kesesuaian yang baik dengan nilai sebesar 0,987 . Nilai CFI sebesar 0,989 menunjukan bahwa model ini memiliki kesesuaian yang baik. Nilai CMIN/DF pada model ini adalah 1,156 sehingga dapat dikatakan telah memiliki indikasi yang baik atau fit.

\section{B. Pembahasan}

Setelah kriteria goodness of fit model terpenuhi, tahap berikutnya adalah uji struktural model hubungan antar variabel. Hubungan antar konstruk yang di hipotesis ditunjukkan oleh nilai bobot regresi. Tabel berikut ini menyajikan bobot regresi dari variabel yang diuji.

Tabel 3. Hasil Regression Weight Analisis Structural Equation Modeling

\begin{tabular}{|c|c|c|c|c|c|c|c|}
\hline & & & Estimate & S.E. & C.R. & $\mathbf{P}$ & Label \\
\hline Kepercayaan_pada PT & $<--$ & Reputasi_PT & ,528 & ,107 & 4,952 & $* * *$ & par_12 \\
\hline Kepercayaan_pada PT & $<--$ & Kualitas_Layanan & ,189 & 077 & 2,461 & 014 & par_13 \\
\hline Keputusan_Memilih PT & $<--$ & Kepercayaan_mahasiswa & ,720 & ,112 & 6,440 & $* * *$ & par_14 \\
\hline $\mathrm{X} 1$ & $<--$ & Reputasi_PT & 1,000 & & & & \\
\hline $\mathrm{X} 2$ & $<--$ & Reputasi_PT & 1,104 & 0,116 & 9,493 & $* * *$ & par_1 \\
\hline $\mathrm{X3}$ & $<--$ & Reputasi_PT & 0,960 & 0,136 & 7,060 & $* * *$ & par_2 \\
\hline $\mathrm{X} 4$ & $<--$ & Kualitas_Layanan & 1,000 & & & & \\
\hline $\mathrm{X} 5$ & $<--$ & Kualitas_Layanan & 0,816 & 0,058 & 14,114 & $* * *$ & par_3 \\
\hline $\mathrm{X6}$ & $<--$ & Kualitas_Layanan & 0,827 & 0,075 & 10,954 & $* * *$ & par_4 \\
\hline $\mathrm{X7}$ & $<--$ & Kualitas_Layanan & 0,900 & 0,072 & 12,493 & $* * *$ & par_5 \\
\hline $\mathrm{X} 8$ & $<--$ & Kualitas_Layanan & 0,931 & 0,066 & 14,012 & $* * *$ & par_6 \\
\hline $\mathrm{X9}$ & $<--$ & Kepercayaan_mahasiswa & 1,000 & & & & \\
\hline $\mathrm{X} 10$ & $\begin{array}{l}<- \\
\end{array}$ & Kepercayaan_mahasiswa & 1,010 & 0,113 & 8,952 & $* * *$ & par_7 \\
\hline $\mathrm{X} 11$ & $<--$ & Kepercayaan_mahasiswa & 1,027 & 0,107 & 9,617 & $* * *$ & par_8 \\
\hline $\mathrm{X} 12$ & $<--$ & Keputusan_Memilih PT & 1,000 & & & & \\
\hline $\mathrm{X} 13$ & $<--$ & Keputusan_Memilih PT & 1,149 & 0,153 & 7,491 & $* * *$ & par_9 \\
\hline $\mathrm{X} 14$ & $<--$ & Keputusan_Memilih PT & 1,177 & 0,153 & 7,702 & *** & par_10 \\
\hline
\end{tabular}


Berdasarkan pada gambar 2 dan tabel 3 diatas terlihat bahwa setiap indikator pembentuk variabel laten menunjukkan hasil yang memenuhi kriteria yaitu nilai $\mathrm{CR}$ di atas 1,96 dengan $\mathrm{P}$ lebih kecil dari pada 0,05 dan nilai lambda atau factor loading yang lebih besar dari 0,5. Hasil tersebut dapat dikatakan bahwa indikator-indikator pembentuk variabel laten tersebut secara signifikan merupakan indikator dari faktor-faktor laten yang dibentuk. Jadi dapat disimpulkan model yang dipakai dalam penelitian ini dapat diterima, selanjutnya dilakukan pengujian terhadap hipotesis penelitian seperti telah yang diajukan pada bagian sebelumnya. Pengujian hipotesis didasarkan atas pengolahan data penelitian dengan menggunakan analisis SEM, dengan cara menganalisis nilai regresi seperti yang ditampilkan pada tabel 3 di atas. Pengujian hipotesis ini dilakukan dengan menganalisis nilai C.R (Critical Ratio) dan nilai P (Probability) pada hasil olah data Regression Weights untuk kemudian dibandingkan dengan batasan statistik yang disyaratkan, yaitu nilai CR (Critical Ratio) di atas 1,96 dan nilai P (Probability) di bawah 0.05. Apabila hasilnya menunjukkan nilai yang memenuhi syarat tersebut, maka hipotesis penelitian yang diajukan dapat diterima.

Secara rinci pengujian hipotesis penelitian akan dibahas secara bertahap sesuai dengan yang telah diajukan. Pada penelitian ini diajukan tiga hipotesis yang selanjutnya pembahasannya dilakukan dibagian berikut ini.

\section{Uji Hipotesis 1}

Hipotesis 1 pada penelitian ini adalah reputasi perguruan tinggi STIE Yapis Dompu berpengaruh positip terhadap kepercayaan mahasiswa. Berdasarkan hasil pengolahan data pada tabel 4 diketahui bahwa nilai CR (Critical Ratio) adalah sebesar 4,952 dengan nilai P (Probability) sebesar 0,000. Kedua nilai ini menunjukkan hasil yang memenuhi syarat, yaitu diatas 1,96 untuk CR (Critical Ratio) dan dibawah 0.05 untuk nilai P (Probability). Hasil ini mengindikasikan bahwa reputasi merupakan variabel yang penting bagi mahasiswa untuk membentuk sikap positif terhadap kepercayaan pada STIE Yapis Dompu. Sehingga dapat dapat disimpulkan bahwa hipotesis 1 pada penelitian ini dapat diterima.

\section{Uji Hipotesis 2}

Hipotesis 2 pada penelitian ini adalah kualitas layanan perguruan tinggi STIE Yapis Dompu berpengaruh positif terhadap kepercayaan mahasiswa. Berdasarkan hasil pengolahan data diketahui bahwa nilai CR (Critical Ratio) untuk hubungan antara kualitas layanan dengan kepercayaan mahasiswa adalah sebesar 2,461 dengan nilai P (Probability) sebesar 0,014. Kedua nilai ini menunjukkan hasil yang memenuhi syarat, yaitu di atas 1,96 untuk CR (Critical Ratio) dan dibawah 0,05 untuk nilai P (Probability). Hasil ini juga mengindikasikan bahwa kualitas layanan merupakan variabel yang penting bagi mahasiswa untuk membentuk sikap positif terhadap kepercayaan pada STIE Yapis Dompu. Sehingga dapat dapat disimpulkan bahwa hipotesis 2 pada penelitian ini dapat diterima.

\section{Uji Hipotesis 3}

Hipotesis 3 pada penelitian ini adalah kepercayaan mahasiswa berpengaruh positif terhadap keputusan memilih STIE Yapis Dompu. Berdasarkan hasil pengolahan data yang ditunjukkan pada tabel 4 diketahui bahwa nilai CR (Critical Ratio) untuk hubungan antara kepercayaan mahasiswa dengan keputusan memilih STIE Yapis Dompu adalah sebesar 6,440 dengan nilai P (Probability) sebesar 0,000. Kedua nilai ini menunjukkan hasil yang memenuhi syarat, yaitu diatas 1,96 untuk CR (Critical Ratio) dan dibawah 0,05 untuk nilai P (Probability). Hasil ini pun mengindikasikan bahwa kepercayaan merupakan variabel yang penting bagi mahasiswa dalam membentuk sikap positif terhadap keputusan memilih STIE Yapis Dompu. Sehingga dapat dapat disimpulkan bahwa hipotesis 3 pada penelitian ini dapat diterima.

Selanjutnya hasil uji dari tiap-tiap hipotesis di atas akan disajikan secara ringkas pada tabel 4 di bawah ini.

Tabel 4. Hasil Uji Hipotesis

\begin{tabular}{|c|c|c|c|}
\hline & Hipotesis & $\begin{array}{l}\text { Nilai CR } \\
\text { dan P }\end{array}$ & Hasil Uji \\
\hline Hipotesis 1 & $\begin{array}{l}\text { Reputasi STIE Yapis Dompu berpengaruh positif dan } \\
\text { signifikan terhadap kepercayaan mahasiswa }\end{array}$ & $\begin{array}{l}\mathrm{CR}=4,952 \\
\mathrm{P}=0,000\end{array}$ & Diterima \\
\hline Hipotesis 2 & $\begin{array}{l}\text { Kualitas layanan STIE Yapis Dompu berpengaruh positif } \\
\text { dan signifikan terhadap kepercayaan mahasiswa }\end{array}$ & $\begin{array}{l}\mathrm{CR}=2,461 \\
\mathrm{P}=0,014\end{array}$ & Diterima \\
\hline
\end{tabular}




\begin{tabular}{llll}
\hline Hipotesis 3 & $\begin{array}{l}\text { Kepercayaan mahasiswa berpengaruh positif dan } \\
\text { signifikan terhadap keputusan memilih STIE Yaps } \\
\text { Dompu }\end{array}$ & $\begin{array}{l}\text { CR }=6,440 \\
\mathrm{P}=0.000\end{array}$ & Diterima \\
& & \\
\hline
\end{tabular}

Sumber: Hasil yang dikembangkan untuk penelitian ini, 2022

\section{SIMPULAN DAN SARAN}

\section{A. Simpulan}

Berdasarkan hasil analisis data dan uji hipotesis, maka dapat ditarik kesimpulan sebagai berikut:

1. Reputasi STIE Yapis Dompu berpengaruh positif dan signifikan terhadap kepercayaan mahasiswa pada perguruan tinggi (PT) STIE Yapis Dompu.

2. Kualitas layanan STIE Yapis Dompu berpengaruh positif dan signifikan terhadap kepercayaan mahasiswa.

3. Kepercayaan mahasiswa pada perguruan tinggi STIE Yapis Dompu berpengaruh positip dan signifikan terhadap keputusan mahasiswa memilih perguruan tinggi tersebut.

\section{B. Saran}

Berdasarkan temuan hasil penelitian, maka dapat direkomendasikan saran sebagai berikut:

1. Untuk penelitian selanjutnya agar menambahkan variabel lain guna penyempurnaan ilmu pengetahuan khususnya dibidang manajemen pemasaran.

2. Untuk penelitian selanjutnya disarankan untuk mempertimbangkan alat analisis lain, misalnya PLS (Partial Least Square).

\section{DAFTAR RUJUKAN}

Doney, P.M and Cannon, J.P. (1997). An Examination of The Nature of Trust in Buyer-Seller Relationship. Journal of Marketing, 61, 35-51.

Dowling, G.R. (2004). Coorporate Reputations : Should You Compete on Yours ? California Management Review, 46, 19-36.

Elrado, Morden H., Srikandi K., dan Edy, T. (2014), Pengaruh Kualitas Layanan Terhadap Kepuasan, Kepercayaan dan Loyalitas pada Pelanggan Jambulawuk Resort. Jurnal Administrasi Bisnis (JAB), Vol.15 N0.2 Oktober 2014.

Ferdinand, Augusty. (2006). Metode Penelitian Manajemen. Semarang : Banadan Penerbit UNDIP.

Ghozali, Imam. (2005). Structural Equation Modelling. Semarang : Banadan Penerbit UNDIP.

Herbig, Paul, John Milewichz \& Jim Golden. (2004). A Model of Reputation Building \& Destruction, Joulnal of Business Research, Vol.31.

Sugiyono. (2012). Metode Penelitian Kuantitatif. Bandung : Alfabeta.

Zulganef, (2002). Hubungan Antara Sikap Terhadap Bukti Fisik, Proses dan Karyawan dengan Kualitas Keterhubungan Serta Perannya Dalam menimbulkan Niat Ulang Membeli dan Loyalitas, Jurnal Riset dan Manajemen, Vol.2 No.3 September 2002. 